\title{
Output-driven Foreign Language Teaching for EFL College Students Based on Blended Learning
}

\author{
Xian Tang \\ School of Foreign Languages \\ Wuhan Textile University \\ Wuhan, China
}

\begin{abstract}
This paper discussed the output-driven teaching of college English courses with the blended learning model. First it introduced the output-driven hypothesis and then it discussed how the output-driven approach could be realized in a blended learning environment. It suggested that the teachers should carefully design the output-driven teaching activities and afterclass tasks to make full use of classroom teaching and online learning, and that the teachers should cultivate students' autonomous learning ability and self-supervision awareness in online learning. It also suggested that the online learning and classroom teaching should become an integrated process. Finally it suggested that the teachers should always improve themselves to catch up with the new times.
\end{abstract}

Keywords - output-driven hypothesis; college English teaching; blended learning; micro-course

\section{INTRODUCTION}

There are several reforms in college English teaching in China, which greatly improves the teaching quality of college English and also enhances college students' English language proficiency. The Teaching Requirements of College English Courses issued by the education ministry in 2007 clearly specify the stipulations of college students' English communicative competence. Bachman pointed out that an English class is a place full of questions and answers and language communication, and that the learning efficiency of a language should be improved through authentic communicative activities [1]. In an EFL (English as a foreign language) class, for example, in the college English class in China, the classroom teaching activities should be designed to help students cultivate and improve language communicative competence. A college English class is a place where students can learn and practice using the language, so there should be enough output activities in the class.

With the development of online learning, blended learning which combines the advantages both of online learning and traditional classroom teaching becomes a popular learning style in higher education. This paper intends to discuss the suitable teaching model that can promote students' language output and improve students' English language level in a blended learning environment.

This paper was supported by the Educational Science Research Project of the Twelfth-five-year Plan in Hubei Province (Project Number: 2014B086), and the Education and Teaching Reform Project of Wuhan Textile University (Project Number: 141141007).

\section{OUTPUT-DRIVEN APPROACH}

\section{A. Input and Output in Foreign Language Teaching}

According to the second language acquisition theory of Krashen, the second language learners should be set in suitable language environment and receive proper language input so that they can acquire the second language naturally. If the present language level of the second language learner is " $\mathrm{i}$ ", the language level of the input materials should be at the " $i+1$ " level so that the input materials can promote learners' second language acquisition [2]. That is, the level of the input materials should be a little higher than the present language level of the second language learners. Krashen's theory stresses the importance of input in second language learning, and has great influence in language teaching.

Contrary to input theory, Swain emphasized the importance of output in language learning. Swain pointed out that through the language output process, language learners can activate their inner cognitive process related to second language acquisition to stimulate their language acquisition [3]. Language output not only can improve learners' language fluency, and can also make the learners adjust their learning strategies to improve their accuracy in language usage. The functions of output in language learning are the following: the stimulation of language learners' syntactical processing, the development of discourse skills and the formation of language learners' own learning style, etc.

For many years, the emphasis of college English teaching was put on the cultivation of students' reading comprehension ability and vocabulary teaching. In such a teaching model, students learned a lot of English vocabulary and could understand English reading materials, but could not use the vocabulary in their speaking and writing. Students' oral English was very poor, and they could not express their ideas fluently in oral English. For many students, the output language ability is their Achilles' heel. There is still a long way to go for teachers to improve students' output language ability to meet the standards of communicative competence specified in the national Teaching Requirements of College English Courses. 


\section{B. Output-Driven Approach in College English Teaching}

"Output-driven hypothesis" was proposed by Professor Wen in 2008 to guide the teaching of English majors in China. She made a comparison between her output-driven hypothesis with Swain's output hypothesis, and concluded the distinct features of her out-driven hypothesis as follows: (1) outputdriven hypothesis is suitable for the medium-level and highlevel learners, but not suitable for the beginners or low-level learners; (2) output-driven hypothesis is limited to the formal foreign language teaching class; (3) output-driven hypothesis specifies that output includes not only speaking and writing, but also translation, which is different from Swain' hypothesis [4].

There are many researches on Professor Wen's Outputdriven hypothesis afterwards, and many researches are made on the application of this hypothesis to non-English majors' teaching. In 2013, Professor Wen made some additional supplement to her output-driven hypothesis as follows: (1) As regards the teaching process, the driving force of output is stronger than that of input, because the output driving force can stimulate the application of language knowledge and spur students' desire to learn new language knowledge; (2) As for the teaching objective, the cultivation of students' English speaking, writing and translation can better satisfy the society's needs of talents [5].

The application of this output-driven hypothesis in college English teaching mainly contains the following aspects: (1) the teaching objective; (2) the course system setting; (3) the teaching process; (4) the teaching evaluation. According to the Teaching Requirements of College English Courses issued by the education ministry in 2007, the teaching objectives of college English include the cultivation of students' communicative competence, autonomous learning, crosscultural communication, and comprehensive application ability of English language. All of these teaching requirements can be achieved through the application of output-driven hypothesis in college English teaching by cultivation of students' output English application ability. The course system of college English should not only includes the teaching of English for General Purposes (EGP), but also includes the teaching of English for Special Purposes (ESP), especially the teaching of English for Academic Purposes (EAP). Hutchinson and Waters classify English for Special Purposes into two categories: English for Academic Purposes (EAP) and English for Occupational Purposes (EOP) [6]. "Fig. 1" shows the college English course system.

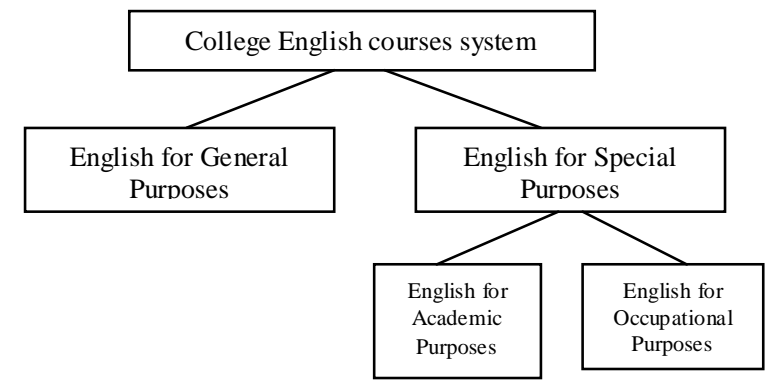

Fig. 1. The college English course system
The EAP teaching is suitable for colleges and universities which can grant students a bachelor's degree and focuses on the cultivation of students' academic knowledge, whereas the EOP teaching is suitable for those occupational colleges that mainly cultivate students' occupational abilities but cannot offer a bachelor's degree. In the EGP teaching, teachers should pay more attention to the training of students' speaking, writing and translation. In the EAP teaching, teachers should cultivate students' ability to use the English language to communicate on matters related to their professional major study which may include the oral presentation of a certain academic topic, the writing of an academic paper the translation of an academic material, etc.

Based on the output-driven hypothesis, in the teaching of EGP and EAP, the teacher should not only train students' listening and reading comprehension, but also pay more attention to students' output abilities, such as speaking, writing and translation. "Fig. 2" shows the input and output in college English teaching.

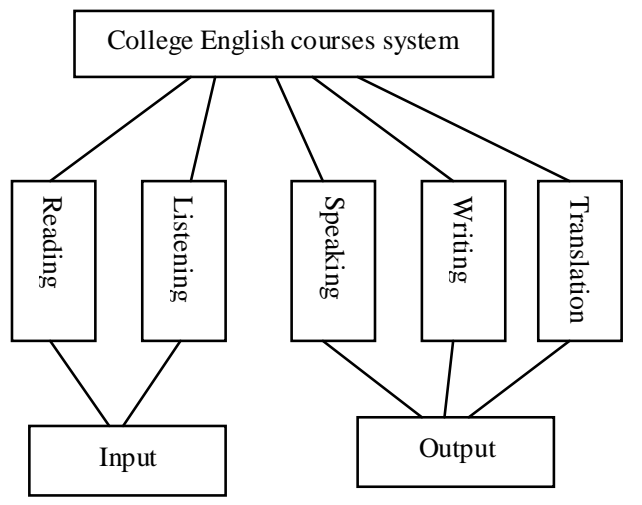

Fig. 2. The college English course system

The input and output are indispensable parts in college English teaching. Although the output-driven approach emphasizes the importance of output in language learning, it does not deny the essential role of input in language learning. The output-driven approach is proposed in a background when teachers and examinations in China excessively stress students' input and ignore students' language output. As the times advances, it is more and more obvious that students' output language abilities, including English speaking, writing and translation are needed in their future workplace and further professional study. Therefore, the cultivation of college students' output language is an urgent task for college English teachers.

\section{OUTPUT-DRIVEN ENGLISH COURSES BASED ON BLENDED LEARNING}

There are still some problems in the teaching of college English courses. The teaching periods of the course are usually not adequate, and the teaching class is often a big class. How to use the limited time to effectively create a high-quality teaching is a headache for college English teachers. With the development of information communications technology, there are several new breakthroughs in educational field. In recent years, blended learning becomes a popular learning style, and 
it can solve many problems that cannot be solved by traditional classroom teaching.

\section{A. Blended Learning}

Blended learning originated from online learning. It owes to Sal Khan, the founder of the Khan Academy that offers a lot of teaching videos and interactive learning material database for tens of thousands of students in at least 200 countries in the world every month and also makes the concept of "blended learning" more and more popular. Before the appearance of the Khan Academy, many students have already experienced blended learning in schools and some training centers.

In 2015, Michael B. Horn and Heather Staker made a clarified people's misunderstanding of blended learning and proposed three parts of the definition of "blended learning" [7].

- Blend learning is an authentic education project, and at least one part of students' learning process must be carried out online where the students can self-regulate their learning time, place, approach or progress.

- At least one part of the students' learning activities is conducted at a place where their learning is supervised outside their family. That is, the students must go to school or a learning center where there are teachers or instructors who guided their study.

- Students' learning process of a certain course must integrate the online learning with the face-to-face classroom learning. These two parts constitute an integrated course. In the online learning part, students' learning progress, learning difficulty, learning time will be recorded, and teachers will match their classroom teaching with students' online learning record.

Blended learning is a flexible learning method, and combines the advantages both of the traditional classroom learning and online learning. When it is used in college English teaching, it can offer solutions to the existing problems.

\section{B. Blended Learning Models for College English Teaching}

Different universities may take different kinds of blended learning models to suit their students. In recent years, a very popular blended learning model is the flipped classroom, which utilizes various kinds of educational technologies to reorganize the teaching activities and reallocate the teaching time and teaching structure and shift the dominance in teaching from teachers to students.

In the flipped classroom teaching, the teacher does not use the classroom time to teach knowledge, but focuses on answering students' questions and guides the students to discuss and do research on issues in their learning. Students learn knowledge by watching teaching videos, reading related learning materials, and discussing with their peer classmates after class. In such a learning model, the teachers do not have to spend time in teaching knowledge in the classroom, but spend time on the interaction and communication with the students according to students' needs. After class, students need to do autonomous learning and self-regulate their learning content, learning progress, learning style, etc. Flipped classroom teaching needs the students to have a good selfregulated ability and self-supervision of their study.

As for the making of the teaching videos, there is a new concept called "micro-course". The appearance of microcourse is the result of the development of education technology, including the popularization of the mobile Internet, mobile devices, and digital campus, and the simplification of courseware making. The popularization of mobile Internet and mobile devices makes the communication between people become easier and convenient, and reduces the cost of making teaching videos. The teachers can make teaching videos at any place and any time they like. The use of mobile devices enables the learners to use their fragmented time to conduct their study at any time and any place as they prefer. The microcourse is very suitable for this kind of fragmented study.

According to the relevant studies, the "micro-course" includes two aspects: the micro-course and the micro-lecture. The micro-lecture refers to the electronic courseware based on micro-course teaching. The electronic courseware includes many short teaching videos which divide the knowledge into several micro units. A lot of micro-lectures constitute a microcourse.

According to Zhao, the development of micro-course can be classified into three stages: micro-materials, micro-lecture and micro-course [8]. In the first stage, micro-materials refers to the teaching materials, including the related teaching videos, the teaching design, subject related courseware, exercises, tests, etc. among which the core content is the teaching videos. All these teaching materials are closely related and become an integrated teaching system. In the second stage, the microlecture refers to the teaching activities and application process based on knowledge points, and mainly includes the teaching task, teaching activities, various interaction and comments and feedback. This stage offers a semi-structural, open and interactive teaching environment where the teachers and students can create a lot of teaching materials related to teaching and learning. In the third stage, micro-course refers to the sum of all the teaching content, teaching process and teaching activities about a certain knowledge point. This sum has a clear subject, and is usually very short, strongly interactive, and easy to use.

The micro-course usually includes four steps (See "Fig. 3") an introduction of a concept, a teaching video, a test and a feedback and summary. In the first step, figures, tables and pictures, preparation tests are used to introduce and demonstrate the teaching content and teaching objective. In the second step, a subject related teaching video shows the knowledge point and it usually takes 5 to 15 minutes. In the third step, students take part in the online test related to the teaching content to examine how students master the knowledge point. In the fourth step, homework exercises or collaborative projects should be finished by students, and usually be handed in online. 


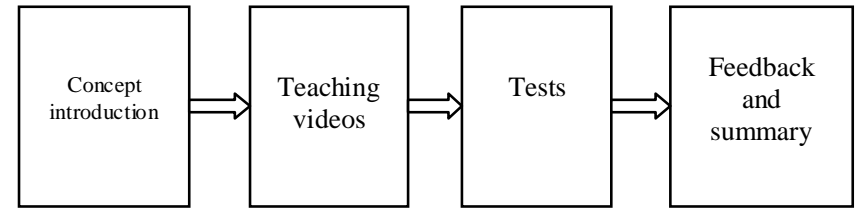

Fig. 3. Four steps of the micro-course

\section{Output-Driven Teaching Based on Blended Learning}

The output-driven teaching of college English can also be designed in a blended learning environment. The teachers should carefully allocate the classroom teaching and students' after-class online learning, and make full use of the two learning styles. The following principles should be complied with when teachers design the blended learning teaching model.

- the output-driven teaching activities and homework tasks should be carefully designed. According to Professor Shu, four teaching conditions must be met in the practice of foreign language teaching: The first condition is that students should have the necessary learning place or environment; the second condition is that the students should have opportunities to apply their language abilities and skills in the real practice context; the third condition is that students can be guided and corrected in the process of problem solving; and the fourth condition is that students can get access to the effective language practice [9]. In the blended learning environment, the classroom teaching can be a place where students are provided with opportunities to practise their language usage, and also a place where students' mistakes can be corrected by their teachers. At the same time, the online learning part can provide students with a lot of opportunities for language usage after class. The online learning can be carried out on a computer, or on a mobile device. The popularization of mobile Internet and $\mathrm{WiFi}$ makes $\mathrm{U}$ learning possible, and provides more opportunities for students to learn and use a foreign language. Only with a smart phone, students can easily get in touch with the latest learning materials about their courses. The human-machine interaction software can be applied in the design of oral English practices. With the access to a computer or a smart phone, a student can conduct an English dialogue with the machine, and the student's oral English performance can be recorded and scored by the computer or the smart phone. Students' scores can be automatically ranked by the computer or the smart phone, so they can know how well they learn and become more motivated to learn. The blended learning, combining the advantages of both the classroom teaching and the online learning, gives the students the needed practice place and environment, and also provides students with teachers' guidance and the machines' ranking. When teachers design the output-driven tasks, they should fully make use of these advantages and provide the students with more practice opportunities. In the practical teaching design, especially in the micro-course part, for the first step, the teachers should make an introduction to the teaching subject. In the second step, the teachers make teaching videos that introduce the basic language points and skills related to the teaching subject. In the third step, teachers can design some output-driven tests, such as translation test, oral English test, or writing tests to examine whether the students master what they learn in the teaching videos. In the fourth step, the output-driven homework tasks should be posted online and let the students to use what they learn in these exercises. Students' online learning process, time and progress can be recorded by the computer, and the teachers can adjust their classroom teaching according to students' learning records.

- teachers should cultivate students' autonomous learning ability and self-supervision awareness. There are two important parts in blended learning---the online learning and the classroom learning, and both parts depend on each other. If the online learning part is not finished or finished well by the students, it can definitely influence teachers' classroom teaching. For example, if a student doesn't watch the teacher's assignment of video watching or doesn't finish the online learning task, he definitely can't catch up with the teacher's classroom teaching, and can't take part in the classroom activities effectively. In such a case, a student's self-supervision awareness plays an important role in the student's online learning. After class, a student is not supervised by teachers, and students should have the self-supervision awareness to carry out the autonomous online learning after class. Therefore, whether the online learning part of blended learning can be successfully carried out greatly relies on the students' autonomous learning. If the students do not finish the online learning section, they certainly cannot achieve the teachers' teaching objective. In such cases, the teaching effect of a blended learning model is greatly influenced by the students' selfregulation. Students' autonomous learning habit is not formed in one day, so the teachers should pay attention to the cultivation of students' independent study.

- the online learning section should be designed to match the classroom teaching. The two parts of blended learning should become an integrated teaching process. The classroom teaching activities are based on students' online learning records, and the teachers should conduct teaching activities that reinforce the students' language skills introduced in the online learning section. This doesn't mean that the students learn something online, and then come back to the classroom to review what they learn online. In order to avoid such as case and avoid the waste of time, a blended learning course should make the use of computers to track every student's learning progress, and make proper arrangement to match the level of teaching materials with the students' learning progress. All the modules in a blended learning course, such as the individual learning module, the group learning module, the exercise module, the examination module, 
etc. should be properly integrated into a reasonable whole to realize the teaching objectives. In a microcourse, the students can watch the teaching videos after class, and finish the corresponding exercises online. For example, the exercise can be an interactive human-computer dialogue, and a student can carry out a dialogue in such a model. The student's dialogue is recorded by the computer, and the student's score is given out automatically by the computer. The analysis of the student's dialogue, including the mistakes, the talking skills, the communicative expressions, etc. will be shown clearly in a report. By reading the analysis report, the student can know how to improve his learning. This analysis report can also be seen by the teachers, so the teachers know what he may do in the future teaching, and how to help the student to improve. The teacher can arrange his teaching according to students' learning report recorded by the computer, and make the classroom teaching to match with students' online learning.

- the teachers should improve their own qualities to match with the latest development of educational technology and try to use them in their teaching. A blended learning can effectively improve teaching effects, but it also demands the teachers to have a good command of educational technologies. Teachers need to learn the new educational technologies, and try to use them in their teaching. Blended learning also demands teachers to have a good command of class management and learning psychology. As a foreign language teacher, he or she should also improve his or her foreign language level, learn some latest foreign language teaching theories and try to apply these theories into the foreign language teaching. The teacher should always rethink his or her teaching, try to improve the teaching and learn something new in the educational field. In higher education, it is always a basic requirement that teachers should learn and improve themselves.

\section{CONCLUSION}

In an information age with the fast development of information communications technology and educational technology, the traditional classroom teaching encounters unprecedented challenges. Teachers should always learn the latest information and knowledge to catch up with the development of the times. An output-driven language teaching of college English courses in a blended learning environment needs the teachers to improve their abilities and can help students improve their English language levels. The outputdriven foreign language teaching is a new teaching method that needs to be applied in the real teaching practice and gradually accumulate practical experience. Future studies might be carried out on how to design the suitable microcourse for output-driven English courses and how to design output-driven learning and practice tasks.

\section{ACKNOWLEDGMENT}

This research was supported by the Educational Science Research Project of the Twelfth-five-year Plan in Hubei Province, China - "Research on the Teaching Models of EAP Based on Blended Learning" (Project Number: 2014B086), and the Education and Teaching Reform Project of Wuhan Textile University - "Research on the Cultivation of English Output Application Ability for Engineering University Students in Provincial Universities" (Project Number: 141141007).

\section{REFERENCES}

[1] L. F. Bachman, Fundamental Considerations in Lnaguage Testing. Shanghai: Shanghai Foreign Language Education Press, 1999.

[2] S. D. Krashen, Second Language Acquisition and Second Language Learning. Oxford: Pergamon Press, 1982.

[3] M. Swain, Communicative Competence: Some Roles of Comprehensible Input and Comprehensible Output in Its Development, in S. Gass \& C. Madden. Eds. Input in Second Language Acquisition. Rowley, M A: Newbury House, 1985.

[4] Q. Wen, "Output-driven hypothesis and the reform of language skill courses for English majors", Foreign Language World, No. 2, 2008, pp. 2-9.

[5] Q. Wen, "The application of output-driven hypothesis in college English teaching: thinking and suggestions", Foreign Language World, No. 6, 2013, pp. 14-22.

[6] T. Hutchinson \& A. Waters, English for Specific Purpose. Cambridge: Cambridge University Press, 1987, pp. 2-45.

[7] M. B. Horn, \& H. Staker, Blended: Using Disruptive Innovation to Improve Schools. John Wiley \& Sons, 2015, pp. 33-35.

[8] G. Zhao, Faculty Development and Design of Micro-lesson \& MOOCs. Beijing: Peking University Press, pp. 21-27.

[9] D. Shu, "An appeal for theories of foreign langugae teaching with Chinese characteristics", Foreign Language World, No. 6, 2005, pp. 2. 